\title{
KINETIKA PENGERINGAN SARI BUAH MENGKUDU DENGAN METODE FOAM MATE DRYING
}

\author{
Kinetic Of Drying Extract Mengkudu Fruit With Foam Mate Drying Method \\ Mhd.Iqbal Nusa \\ Program Studi Teknologi Hasil Pertanian \\ Email : nusaiqbal@gmail.com
}

\begin{abstract}
The objective of this reasearch to study the effect of concentration egg albumin as foam agent, and duration of time whipping to physical caracteristic foam of the mengkudu fruit juice,and kinetic of foam mate drying. The stage of the reasearch have compiled to obtain juice mengkudu fruit by mechanical extraction. To adding maltodextrin (foaming stability) 5\% $(w / w)$, egg albumin (foaming agent) as the first factor four level as 0,25\%; $5 \% ; 7,5 \%$; and 10 $\%(w / w)$. Foaming process by whipping as the second factor with four level of duration time whipping 5; 10; 15; and 20 minute. Quality of foaming indicators were cracteristic foaming as foaming expansion and density of foaming. And then foaming material to dry with foam mate thin drying methode at $70^{\circ} \mathrm{C}$ to equilibrium moisture content. Measurement of paramater were characteristic physical of foaming, alteration of moisture content, the rate of drying, difusivitas moisture, and moisture content. The result of reasearch data have indicated the corelation increasing of foaming expansion with adding egg albumin concentration and prolong duration time of whipping, increasing of rate of drying and number of difusivitas moisture foam mate drying.
\end{abstract}

Key word: Kinetical of drying; Physical characteristic of foaming; and foam mate drying

\section{A. PENDAHULUAN}

Mengkudu salah satu tumbuhan obat yang sering dikonsumsi oleh masyarakat. Buah Mengkudu dikonsumsi oleh masyarakat sebagai obat tradisional untuk pencegahan dan pengobatan berbagai macam penyakit. Beberapa penelitian melaporkan tentang khasiat mengkudu antara lain sebagai efek kemoterapi (Karamchesi et al, 2014), anti depresan (Deng et al, 2011), aktivitas hepatoprotektif (Wang et al, 2008), antioksidan (Saminathan et al, 2014), antidisplipedemia (Mandukhail et al, 2010), antimikroba (Usha et al, 2010), efek immunomodulator (Palu et al, 2008). Aktifitas tersebut diperkirakan salah satunya karena adanya kandungan senyawa aktifitas antioksidan dalam buah mengkudu dengan kandungan flavonoid dan senyawa fenolik (Rao dan Subramanian, 2009). Efek buah mengkudu diantaranya sebagai antitrombolitik, antioksidan, analgesik, anti inflamasi dan aktifitas xanthine oxidase inhibitor yang dapat menurunkan tekanan darah dan vasodilatasi pembuluh darah (Ayanblu, 2006). Untuk menghindari kerusakan dan kehilangan pasca panen dan mempertahankan kualitas produk olahan buah mengkudu, dapat dilakukan pemanfaatan buah mengkudu matang fisiologis menjadi produk minuman fungsional dalam bentuk jus (sari buah), kemudian melalui proses pengeringan sari buah dihasilkan serbuk minuman cepat larut (serbuk instan).

Pemilihan teknik pengeringan pengolahan buah dan sayuran harus mempertimbangkan karakteristik buah dan sayuran yang sensitif terhadap suhu pengeringan yang tinggi, sehingga menyebabkan kehilangan kandungan nutrisi, aroma, dan warna. Metode pengubahan bahan cair menjadi bahan dengan struktur berbusa, kemudian bahan ditempatkan dalam ruang pengering sebagai lembaran atau lapisan tipis (Foam mat drying technique). Kondisi ini akan memperluas permukaan kontak antara bahan dengan udara pengering, laju perpindahan panas konveksi dan difusivitas uap air dari bahan ke udara pengering akan meningkat, sehingga dapat memperbesar laju pengeringan bahan pada suhu yang lebih rendah. Teknik pengeringan ini akan 
membantu dalam pengeringan bahan yang rentan terhadap suhu tinggi (Rajkumar et al., 2007; Thuwapanichayanan et al., 2008). Keunggulan lain dari pengeringan dengan pembusaan ini adalah dapat mempertahan sifat yang diinginkan pada produk seperti mempertahankan kandungan senyawa yang mudah untuk menguap (volatiles) (Ratti dan Kudra, 2005; Kadam dan Balasubramanian, 2011). Pengeringan bahan pangan cair dengan pembusaan ini dilakukan dengan menggabungkan bahan yang akan dikeringkan dengan bahan pemicu pembentukan busa (foaming agent), bahan penstabil busa (foam stabilizer), dan kemudian dilanjutkan dengan pengadukan (whipping) sehingga bahan berubah bentuk dalam struktur busa yang stabil sebelum dilakukan pengeringan (Morgan et al. 1960; Hart et al. 1963).

Peranan bahan pemicu pembusaan (foaming agents) terhadap kinerja pengeringan dapat ditentukan dari karakteristik busa yang dihasilkan, dan kualitas bubuk dari produk keringnya. Perbedaan karakteristik busa yang dihasilkan dipengaruhi oleh beberapa faktor yaitu; penggunaan bahan pemicu pembusaan yang berbeda, konsentrasi bahan pemicu pembusaan, jumlah padatan terlarut di dalam bahan yang akan dikeringkan, lamanya waktu pengadukan (Whipping time), dan suhu ruang pengering (Javed et. al.2018). Penggunaan bahan pemicu pembusaan (Foaming Agents) seperti protein putih telur (Albumin), Isolat protein kedele (Soy proteins), glycerol Monostearat, dan carboxymethyl cellulosa sudah dilakukan (Muthukumaran et. al. 2007). Pemakaian putih telur (white eggs) sebagai bahan pemicu pembusaan dengan karakteristik yang mendukung seperti kestabilan struktur busa, dan penambahan volume busa, (Javed et. all.2018). Pengeringan bubur daging buah Aril dengan teknik foam mat drying menunjukkan bahwa, konsentrasi methyl celulosa dan lama waktu pengadukan (whipping time) mempengaruhi terhadap karakteristik busa, difusivitas uap air, laju pengeringan, dan sifat-sifat fisiko kimia produk yang dapat dipertahankan (Khamjae dan Rojanakorn, 2018). Pengeringan bubur daging buah mangga menggunakan putih telur (Albumin) pada konsentrasi $3 \%$ $(\mathrm{w} / \mathrm{w})$ dan suhu pengering $65^{\circ} \mathrm{C}$ menunjukkan kombinasi perlakuan yang terbaik terhadap angka difusivitas uap air, laju pengeringan, dan kadar karoten bubuk yang dihasilkan (Robin, A.Wilson et al. 2012). Pengeringan lapisan tipis bubur daging buah mangga yang pembusaannya menggunakan putih telur dan methyl celulosa dengan variasi ketebalan lapisan bahan dengan metode pengeringan lapisan tipis, menunjukkan peningkatan laju pengeringan dengan mengurangi ketebalan lapisan (Rajkumar et al. 2007).

Berdasarkan uraian di atas perlu dilakukan penelitian penerapan teknik pengeringan Foam Mat Drying pada pengolahan sari buah mengkudu menjadi serbuk minuman Instan. Aspek yang dipelajari berkaitan dengan pengaruh konsentrasi pemakaian putih telur sebagai bahan pemicu pembentukan busa (foaming Agents), dan lama waktu pengadukan (Whipping Time) terhadap karakteristik pembusaan, kinerja pengeringan sari buah Mengkudu.

\section{B. BAHAN DAN METODE}

\section{Tempat dan waktu penelitian}

Penelitian dilaksanakan di Laboratorium Teknologi Hasil Pertanian yang dimulai dari bulan Agustus sampai selesai dalam rentang waktu 4 (empat) bulan.

\section{Prosedur penelitian}

\section{Penyiapan bahan olah}

Buah mengkudu yang sudah matang fisiologis di panen, disortasi untuk mendapatkan kualitas yang seragam, dicuci bersih kemudian disimpan di dalam lemari pendingin untuk tujuan rekondisi buah. Proses pengambilan cairan buah mengkudu secara ekstraksi mekanis, melalui pengecilan ukuran (pemotongan dan penghancuran (blendering basah) dihasilkan bubur buah kemudian dipisahkan antara fraksi padatan dan fraksi cairan. Sari buah mengkudu yang diperoleh kemudian dilakukan pengukuran densitas dan kandungan padatan terlarut. Besaran fisik digunakan sebagai indikator dalam mempersiapkan kondisi bahan cairan yang relatif seragam.

\section{Bahan pembentuk busa}


Mhd.Iqbal Nusa / Agrintech | Jurnal Teknologi Pangan dan Hasil Pertanian 3 (1) 2019,28-36.

Campuran bahan terdiri dari sari buah mengkudu, ditambahkan sebanyak $5 \%$ $(\mathrm{w} / \mathrm{w})$ Maltodekstrin sebagai bahan penstabil busa dan meningkatkan angka padatan terlarut bahan, sekaligus berperan sebagai enkapsulan. Kemudian dilakukan penambahan protein putih telur ( egg albumin) yang berfungsi sebagai bahan pemicu pembusaan (foaming Agents) sesuai dengan faktor perlakuan I dengan taraf $0,25 \%, 0,5 \%$, 0,75\%, dan $10 \%(\mathrm{w} / \mathrm{w})$.

\section{Pembusaan dan pengukuran kualitas}

Pada tahapan ini campuran bahan dilakukan pengadukan (Whipping) dengan lama waktu pengadukan yang bervariasi sebagai Faktor perlakuan II dengan taraf 5, 10, 15, dan 20 menit. Kualitas hasil proses pembusaan ditentukan dengan mengukur karakteristik busa antara lain; sifat fisik seperti densitas busa, penambahan volume busa (daya pengembangan), dan stabilitas busa.

\section{Pengeringan busa lapisan tipis (foam mat drying) \\ Bahan yang sudah berubah} dalam struktur busa ditempatkan di atas wadah membentuk lapisan, dan dikering sebagai lapisan tipis untuk mempersingkat waktu pengeringan. Pengeringan dilakukan pada suhu $70{ }^{\circ} \mathrm{C}$ dihentikan sampai tercapai kadar air kesetimbangan untuk kondisi tersebut. Selama proses pengeringan ditentukan laju pengeringan, dan difusivitas uap air

\section{Angka rasio perubahan kadar air}

Perubahan kadar air sampel diukur menurut periode waktu pengeringan dinyatakan sebagai berikut (Kadam et al.2011; Goyal, et all. 2007)

$M R=\frac{(M-M e)}{\left(M_{0}-M e\right)}$

Dimana Kadar air kesetimbangan relatif sangat kecil, sehingga dapat diabaikan, maka rasio perubahan kadar per periode waktu pengeringan dapat dinyatakan juga

$$
M R=\frac{M}{M_{0}} \text {. }
$$

\section{Difusifitas uap air}

Menurut persamaan difusi Ficks untuk bentuk geometris bahan berbentuk lempeng, difusifitas uap air selama proses pengeringan lapisan tipis berlaku persamaan berikut (Doymaz, 2006; Crank, 1975)

$$
M R=\frac{8}{\Pi^{2}} \exp \left(\frac{-\Pi^{2} \text { Deff } T}{4 \Pi L^{2}}\right) .
$$

Dimana; Deff adalah angka difusifitas uap air (meter2/detik), $\mathrm{T}$ adalah waktu periode pengeringan (jam), L adalah ketebalan lapisan bahan (meter), dan konstanta phi.

Persamaan (3) dapat ditulis sebagai berikut

$$
D e f f=\frac{\ln M R-\ln \frac{8}{\Pi^{2}}}{\left(\frac{\Pi^{2} T}{4 L^{2}}\right)}
$$

\section{HASIL DAN PEMBAHASAN \\ Karakteristik pembusaan}

Berdasarkan hasil pengamatan terhadap parameter karakteristik fisik pembusaan pengaruh kombinasi perlakuan yaitu penambahan konsentrasi protein putih telur (A) sebagai bahan pemicu pembentukan busa (foam agent), dan lama waktu pengadukan (duration time of wheapping) (M) terhadap daya pengembangan busa dan densitas busa dari bahan ekstrak sari buah mengkudu secara kuntitatif dapat dilihat pada tabel 1 berikut

Tabel 1. Pengaruh perlakuan terhadap Karakteristik pembusaan

\begin{tabular}{|c|c|c|c|}
\hline \multicolumn{2}{|c|}{ Perlakuan } & $\begin{array}{c}\text { Rerata Daya } \\
\text { pengembang } \\
\text { busa } \\
(\%)\end{array}$ & $\begin{array}{c}\text { Rerata } \\
\text { Densitas } \\
\text { busa } \\
\text { (gram/cm3) }\end{array}$ \\
\hline \multirow{4}{*}{ A1 } & M1 & 33 & 0.521 \\
\cline { 2 - 4 } & M2 & 41 & 0.501 \\
\cline { 2 - 4 } & M3 & 45 & 0.500 \\
\cline { 2 - 4 } & M4 & 43 & 0.508 \\
\hline \multirow{4}{*}{ A2 } & M1 & 55 & 0.473 \\
\cline { 2 - 4 } & M2 & 83 & 0.404 \\
\cline { 2 - 4 } & M3 & 96 & 0.379 \\
\cline { 2 - 4 } & M4 & 96 & 0.380 \\
\hline \multirow{4}{*}{ A3 } & M1 & 59 & 0.467 \\
\cline { 2 - 4 } & M2 & 97 & 0.380 \\
\cline { 2 - 4 } & M3 & 109 & 0.358 \\
\cline { 2 - 4 } & M4 & 120 & 0.332 \\
\hline \multirow{4}{*}{ A4 } & M1 & 74 & 0.428 \\
\cline { 2 - 4 } & M2 & 123 & 0.352 \\
\cline { 2 - 4 } & M3 & 140 & 0.328 \\
\cline { 2 - 4 } & M4 & 148 & 0.318 \\
\hline
\end{tabular}


Keterangan : A1 (2,5\%),A2 (5,0\%), A3 (7,5\%), A4 (0\%),M1 (5 menit), M2 (10 menit), M3 (15 menit), M4 (20 menit).

Pada tabel 1 diatas dapat dilihat bahwa, dengan penambahan konsentrasi protein putih telur sebagai bahan pemicu pembusaan dan memperpanjang waktu pengadukan secara kuntitatif akan meningkatkan daya pengembangan busa dan sebaliknya akan menurunkan angka densitas busa bahan akibat dari pertambahan volume busa. Penambahan bahan pemicu pembusaan membuat campuran sebagai sistem koloid. Efek pengadukan terhadap campuran bahan akan membentuk gelembung- gelembung udara (globula). Semangkin diperpanjang waktu pembusaan yaitu memperlama pengadukan terjadi penambahan jumlah globula yang diisi udara. Pengaruh kombinasi perlakuan terhadap daya pembusaan dan densitas busa digambarkan pada gafik berikut

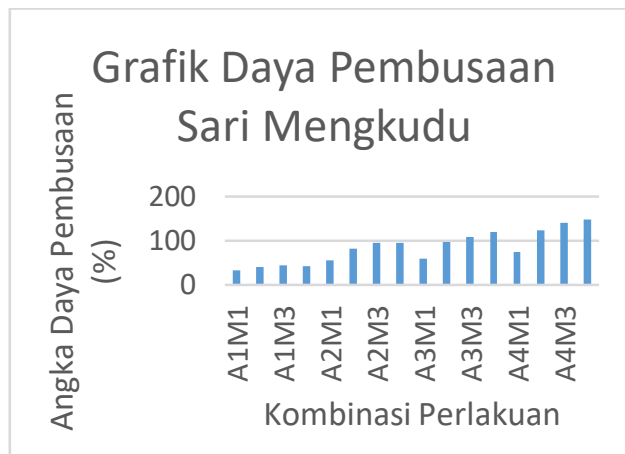

Gambar 1. Pengaruh kombinasi perlakuan terhadap daya pembusaan

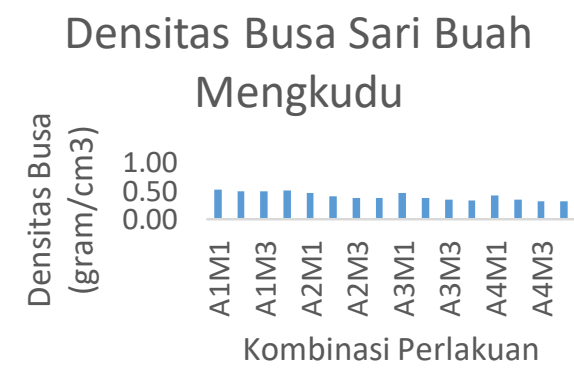

Gambar 2. Pengaruh kombinasi perlakuan terhadap angka densitas bahan busa

\section{Laju pengeringan}

Kinetika pengeringan foam mat drying dipengaruhi oleh karakteristik pembusaan. Peningkatan laju pengeringan dapat ditentukan dari dari penurunan kadar air bahan selama interval waktu pengeringan. Pada grafik laju pengeringan dapat dilihat di periode awal pengeringan laju pengeringan relatif konstan ditunjukan oleh garis kurva yang mendatar sepanjang interval waktu pengeringan. Pada fase ini panas dari udara pengering diterima bahan untuk memenuhi kebutuhan panas laten penguapan air, kandungan air bahan berada pada status air bebas. Sejalan dengan penambahan lama waktu pengeringan, laju penurunan kadar air semangkin cepat. Panas yang diterima bahan akan semangkin terakumulasi, bahan yang sudah membusa akan memperbesar luas permukaan kontak udara pengering dengan bahan, dan luas bidang penguapan air di dalam bahan.

Perubahan kadar air bahan selama interval 10 menit waktu pengeringan menunjukan laju pengeringan bahan yang disajikan pada gambar kurva laju pengeringan berikut

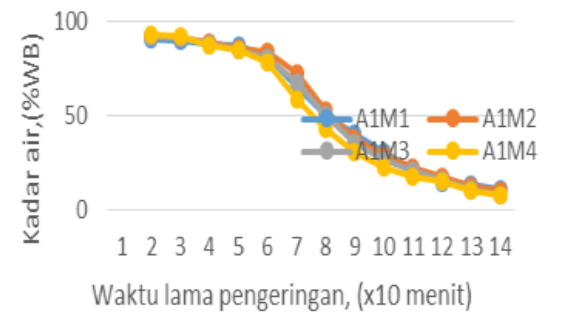

Gambar 3 a. Kurva laju pengeringan bahan busa dengan konsentrasi putih telur 2,5\% (A1)

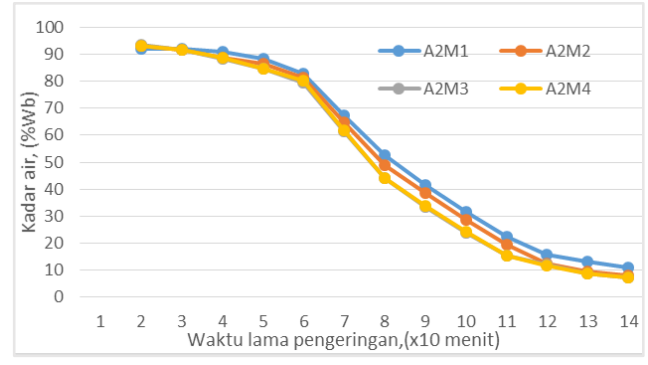

Gambar 3b. Kurva laju pengeringan bahan busa dengan konsentrasi putih telur $5 \%$ (A2)

Pada gambar 3a menunjukkan laju penurunan kadar air campuran sari buah mengkudu, maltodekstrin, dan penambahan 2,5\% protein putih telur (A1) yang kemudian dilakukan pembusaan dengan variasi waktu 
pangadukan selama 5 menit (A1M1), pengadukan selama 10 menit (A1M2), pengadukan selama 15 menit (A1M3), dan pengadukan selama 20 menit (A1M4). Penurunan kadar air lebih cepat terjadi pada bahan dengan lama pengadukan 20 menit (A1M4).

Pada gambar $3 \mathrm{~b}$ menunjukkan laju penurunan kadar air bahan sari buah mengkudu, maltodekstrin, dan penambahan $5 \%$ protein putih telur yang kemudian dilakukan pangadukan selama 5 menit (A2M1), pengadukan selama 10 menit (A2M2), pengadukan selama 15 menit (A2M3), dan pengadukan selama 20 menit (A2M4). Hal yang sama penurunan kadar air lebih cepat terjadi pada lama waktu pengadukan 20 menit (A1M4).

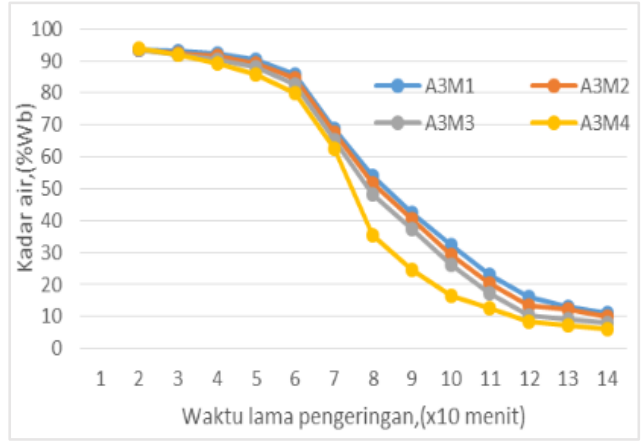

Gambar 3.c. Kurva laju pengeringan bahan busa dengan konsentrasi putih telur 7,5 \% (A3)

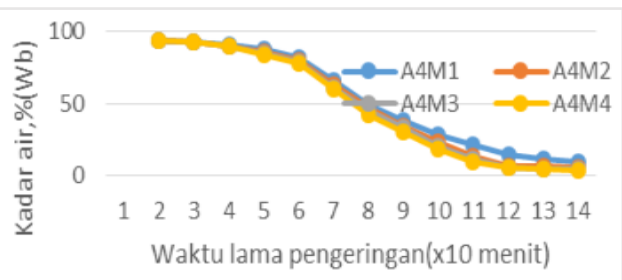

Gambar 4d. Kurva laju pengeringan bahan busa dengan konsentrasi putih telur $10 \%$ (A4)

Pada gambar 3c dapat dilihat laju penurunan kadar air bahan ampuran sari buah mengkudu, maltodekstrin, dan penambahan $7,5 \%$ protein putih telur kemudian dilakukan; pangadukan; selama 5 menit (A3M1), pengadukan selama 10 menit (A3M2), pengadukan selama 15 menit (A3M3), dan pengadukan selama 20 menit (A3M4). Hal yang sama penurunan kadar air lebih cepat terjadi pada lama waktu $\begin{array}{llll}\text { pengadukan } 20 & \text { menit (A3M4). }\end{array}$
Penambahan konsentrasi putih telur sebesar 7,5 \% (A3) akan memicu pembusaan, sehingga penurunan kadar air akan semangkin besar dengan semangkin bertambahnya luas permukaan kontak bahan dengan udara pengering dengan waktu pembusaan yang lebih lama yaitu 20 menit (M4).

Pada gambar $4 \mathrm{~d}$ menunjukkan laju penurunan kadar air bahan dengan pengering foam mat drying campuran sari buah mengkudu, maltodekstrin, dengan penambahan $10 \%$ protein putih telur dan dilakukan pangadukan selama 5 menit (A4M1), pengadukan selama 10 menit (A4M2), pengadukan selama 15 menit (A4M3), dan pengadukan selama 20 menit (A4M4). Semangkin meningkat penambahan bahan pemicu busa dan bertambahnya waktu pengadukan akan memperbesar daya pembusaan bahan. Peningkatan daya busa akan memperbesar luas permukaan kontak, sehingga memudahkan jalan proses pengeringan. Pada kurva laju pengeringan dapat dilihat bahwa setelah 40 menit berjalan peoses pengeringan, laju penurunan kadar air semangkin cepat. Hal ini disebabkan panas yang diterima bahan akan semangkin terakumulasi, bahan yang sudah membusa akan memperbesar luas permukaan kontak udara pengering dengan bahan, dan luas bidang penguapan air di dalam bahan, sehingga penurunan kadar air lebih cepat terjadi.

\section{Difusifitas uap air}

Pergerakan uap air dari dalam ke luar bahan selama pengeringan merupakan fenomen perpindahan massa melalui mekanisme difusi. Berdasarkan perubahan angka difusifitas efektif uap air menunjukkan besaran yang berbeda diantara karakteristik fisik busa dan periode waktu pengeringan seperti pada gambar kurva perubahan angka difusifitas uap air berikut 


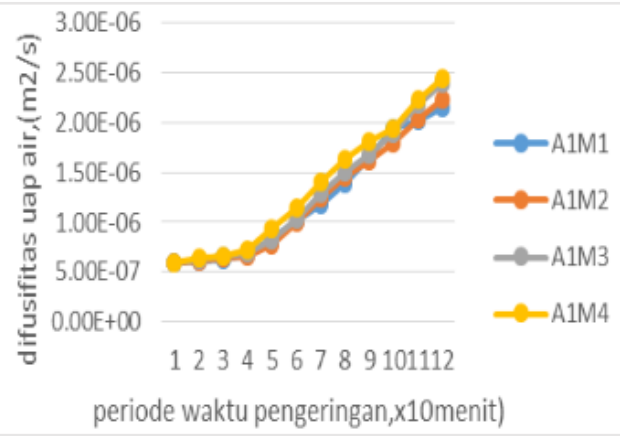

Gambar 2a . Kurva perubahan angka difusifitas uap air bahan dengan konsentrasi Albumin 2,5\%

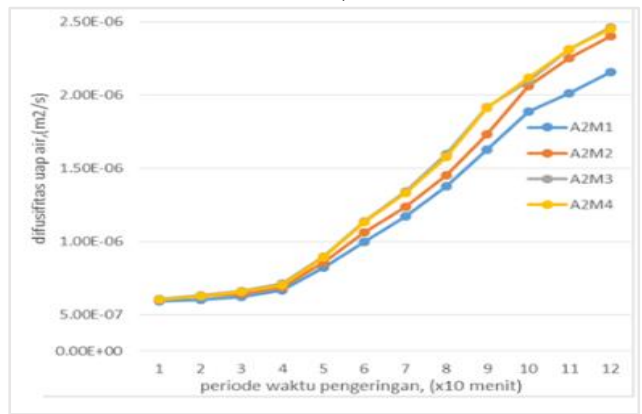

Gambar $2 \mathrm{~b}$. Kurva perubahan angka difusifitas uap air bahan dengan konsentrasi Albumin 5\%

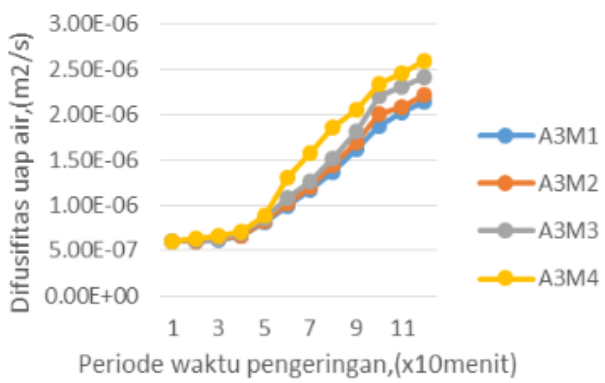

Gambar 2c. Kurva perubahan angka difusifitas uap air bahan konsentrasi Albumin 7,5\%

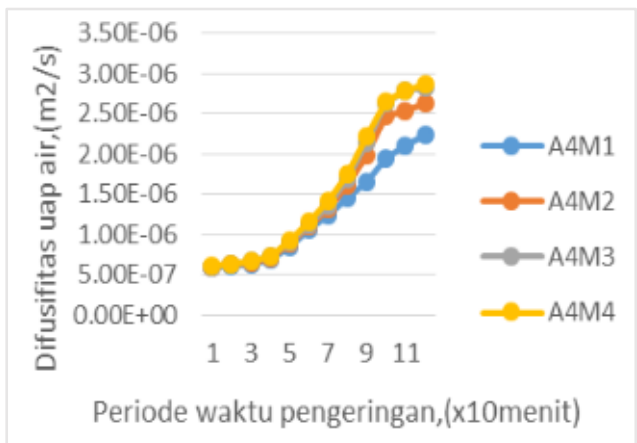

Gambar 2d. Kurva perubahan angka difusifitas uap air bahan dengan konsentrasi Albumin $10 \%$
Pada gambar 2a, 2b, 2c, dan 2d diatas dapat dilihat fenomena bahwa pada periode waktu pengeringan 40 menit hingga 100 menit terjadi peningkatan yang tajam angka difusifitas uap air. Hal ini apabila dikaitkan dengan pola penurunan kadar air bahan pada kurva laju pengeringan pada periode pengeringan yang sama terjadi penurunan angka kadar air yang tajam, sehingga pada periode tersebut laju pengeringan meningkat. Peningkatan laju pengeringan yang meningkat ditunjukan oleh penurunan kadar air bahan yang besar yang mekanisme pergerakan uap air dari dalam bahan keluar adalah fenomena difusi uap air.

\section{KESIMPULAN}

1. Penambahan Konsentrasi putih telur sebagai bahan pemicu pembentukan busa (foaming Agent), dan bertambah lama waktu pengadukan (duration of time whipping) dapat meningkatkan kualitas pembusaan yaitu peningkatan angka pengembangan busa, dan penurunan angka densitas bahan yang membusa

2. Peningkatan kualitas pembusaan akan meningkatkan laju perpindahan panas dan massa dalam proses pengeringan menggunakan teknologi foam mat drying

\section{SARAN}

Penerapan teknik pengeringan Foam Mat Drying dalam pembuatan sebuk minuman dari sari buah mengkudu, penambahan bahan pemicu pembentukan busa yaitu protein putih telur dengan konsentrasi $10 \%$, dan lama waktu pengadukan 20 menit menghasilkan kualitas pembusaan yang baik dan laju pengeringan yang tinggi.

\section{DAFTAR PUSTAKA}

Akintoye, O.A., and Oguntunde, A.O.

(1991). Preliminary investigation on the effect of foam

Ayanblu F, Wang MY, Peng L, Nowicki J, Anderson G, Nowiciki D. 2006. Antithrombotic effect of Morinda citrifolia (Noni) fruit juice on the jugular vein thrombosis induced by ferric chloride in male adult 
SD rats. Arteriosclerosis

Thrombosis and Vascular

Biology. ;26

Badan Pusat Statistik, (2014). Perkiraan potensi produksi tanaman obat. Laporan Survei pertanian 2014.

Bag, S., Srivastav, P., and Mishra, H. (2011). Optimization of process parameters for foaming

Bangun AP, Sarwono B. 2004. Khasiat dan Manfaat Mengkudu. Jakarta. AgroMedia pustaka.

Campbell, C.H. (1917). Drying milk. US Patent 1250427.

Carp, D., Baeza, R., Bartholomai, G., and Pilosof, A. (2004). Impact of proteins-carrageenan interactions on foam properties. LWT - Food Science and Technology, 37: 573-580. characteristics and quality of banana foam mat. Journal of Food Engineering, 86 (4): 573- 583.

Deng S, West BJ. 2011. Antidepressant effects of Noni fruit and its active principals. Asian Journal of Medical Sciences. hal.7983.

Dickinson, E. (1998). Proteins at interfaces and in emulsions Stability, rheology and interactions. Journal of Chemical Society, Faraday Trans. 94: 16571669.

Djauhariya, Endjo. Mengkudu (Morinda citrifolia L.) Tanaman Obat Potensial. Balai Penelitian Tanaman Rempah dan Obat. Pengembangan Teknologi TRO. 2003; 15(1) : 1-16.

Falade, K., Adeyanju, K., and Uzo-peters, P. (2003). Foam-mat drying of cowpea Vigna

Falade, K., and Onyeoziri, N. (2012). Effects of cultivar and drying method on color, pasting and sensory attributes of instant yam (Dioscorea rotundata) flours. Food and Bioprocess Technology, 5: 879-887.

Falade, K.O., and Okocha, J.O. (2012). Foam-mat drying of plantain and cooking banana (Musa spp.). Food Bioprocess Technology, 5, 1173-1180. Food Processing and Preservation, 35(4): 488-495.

fresh and stored foam mat dried Mandarin powder. International
Journal of Food Science and Technology, 46: 793-799

Hart MR, Graham RP, Ginnette LF and Morgan AI, Foams for foam-mat drying. Food Technology, 17, 1302-1304, 1963

Hassan, M. and Ahmed, J. (1998). Sensory quality of foam-mat dried pineapple juice powder,Indian Food Packer, 52(7): 31-33.

Kadam D M and Balasubramanian S, Foam mat drying of tomato juice. Journal of food processing and preservation, 35(4), 488-495, 2011.

Kadam, D. M., Patil, R.T., and Kaushik, P. (2010 a). Foam mat drying of fruit and vegetable

Kadam, D. M., Wilson, R.A., and Kaur, S. (2010 b). Determination of biochemical properties of foammat dried mango powder. International Journal of Food Science and Technology, 45: 1626-1632

Kadam, D.M., and Balasubramanian, S. (2011a). Foam mat drying of tomato juice. Journal of Kadam, D.M., Rai, D.R., Patil, R., Wilson, R.A., Kaur, S., and Kumar, R. (2011b).

Kadam, D.M., Wilson, R.A., and Kaur, S. (2011 c). Influence of foam-mat drying on quality of tomato powder. International Journal of Food Properties, 15 (1): 221-220

Kadam, D.M., Wilson, R.A., Kaur, S., and Manisha (2012 a). Influence of foam mat drying on quality of tomato powder. International Journal of Food Properties, 15: 211-220.

Kadam, D.M., Wilson, R.A., Kaur, V., Chadha, S., Kaushik, P., Kaur, S., Patil, R.T., and Rai, D.R. (2012b). Physicochemical and microbial quality evaluation of foam-matdried pineapple powder. International Journal of Food Science and Technology, 47: 1654-1659.

Karamcheti SA, Satyavati D, Subramanian NS, Pradeep HA, Pradeep KC, Deepika PG. 2014.

Chemoprotective effect of ethanolic extract of Morinda citrifolia against Cisplatin 
induced nephrotoxicity. The Pharma Innovation. Hal: 8491

Karim, A.A., and Wai, C.C. (1999). Foammat drying of starfruit (Averrhoa carambola L.) puree: Stability and air drying characteristics. Food Chemistry, 64 (3): 337-343.

Klitzing, R. V. and Müller, H. J. (2002). Film stability control. Curr. Opin. Colloid Interface Sci. 7: 42-49.

Kwon, Y.S., \& Kim, C.M., 2003, Antioxidant Constituent from the Stem of Sorghum bicolor, Arch. Pharm. Res., 26 (7) : 535-539.

Mandukhail SR, Nauman A, Anwarul HG. 2010. Studies on antidyslipidemic effects of Morinda citrifolia (noni) fruit, leaves and root extracts. Lipids in Health Dis. hal.16.

Materials: a review. Journal of Food Engineering, Amsterdam, 61 (3): 373-386.

MathivananN, SurendiranG, Srinivasa K,SagadevanE, MalarvizhiK. Review on the current scenario of Noni research: Taxonomy, distribution, chemistry, medicinal and therapeutic values of Morinda citrifolia. International Journal of Noni Research. 2005;1(1)

Mayor, L., and Sereno, A.M. (2004). Modeling shrinkage during convective drying of food

Mink, L.D. (1939). Egg material treatment. US Patent 2183516.

Mink, L.D. (1940). Treatment of egg whites. US Patent 2200963.

Morgan AI, Graham RP, Ginnette LF and Williams GS, Recent developments in foam mat drying. Food technology, 15, 37 39, 1961

Morgan, A. I., Graham, R.P., Ginnette, L.F., and Williams, G.S. (1961). Recent developments in foam-mat drying. Food Technology, 15: 3739.

Of bael (Aegle marmelos; L.) fruit pulp. Food and Bioprocess Technology, 4: 1450 -1458.

P.Rajkumar, R.Kailappan, R.Vishwanathan, K.Parvathi, G.Raghavan and V.Orsat. 2007 . Thin Layer Drying Study on Foamed Mango Pulp".
Agricultural Engineering International: the CIGR Ejournal Manuscript. FP 06 024. Vol. IX. March,.

Palu AK, Kim AH, West BJ, Deng S, Jensen J, White L. 2008. The effects of Morindacitrifolia L. (noni) on the immune system: Its molecular mechanisms of action. Journal of Ethnopharmacology. hal.6-508

Prasetyaningrum, A., and Djaeni, M. (2012). Drying Spirulina with Foam Mat Drying at Medium Temperature. International Journal of Science and Engineering, 3(2):1-3.

products. In Drying of foods, vegetables and fruits - Volume 1 (S.V. Jangam, C.L. Law and A.S. Mujumdar, eds) pp. 113-124, ISBN: 978-981-08-6759-1, Published in Singapore.

Rajkumar, P., Kailappan, R., Viswanathan, R., and Raghavan, G.S.V. (2007). Drying characteristics of foamed alphonso mango pulp in a continuous type foam mat dryer. Journal of Food Engineering, 79: 1452-1459.

Ratti C and Kudra T, Drying of foamed materials opportunities and challenges. In proceeding 11th polish Drying symposium. Sept, pp. 13-16. CD-ROM. Poznar, Poland, 2005.

Ratti, C. (2011). Hot air and freeze drying of high-value foods: a review. Journal of Food Engineering, 49 (4): 311-319.

Saminathan M, Ram BR, Kuldeep D, Babu LJ, Subramaniyam S, Gopikunte JR. 2008. Effects of Morinda citrifolia (noni) fruit juice on antioxidant, hematological and biochemical parameters in NMethylNNitrosourea (NMU) induced mammary carcinogenesis in spraguedawley rats. International Journal of Pharmacology. hal.19-109

Sankat, C.K., and Castaigne, F. (2004). Foaming and drying behavior of ripe bananas. LWT-Food Science and Technology, 37: 517-525.

Sjabana, Dripa. Mengkudu.Jakarta: Salemba Medika.2002 stabilizers on the physical characteristics 
Mhd.Iqbal Nusa / Agrintech | Jurnal Teknologi Pangan dan Hasil Pertanian 3 (1) 2019,28-36.

and reconstitution properties of foam-mat dried soymilk. Drying Technology, 9 (1): 245-262. Thuwapanichayanan, R.,

Prachayawarakorn, S., and Soponronnarit, S. (2008). Drying unguiculata) using glyceryl monostearate and egg albumin as foaming agents. European Food Research and Technology. 217: 486-491.

Usha R, Sangeetha S, Palaniswamy M .2010. Antimicrobial activity of a rarely known species, Morinda citrifoliaL. Ethnobotanical Leaflets. hal.11-306
Walsh, D.J., Russell, K., and Fitzgerald, R.J. (2008). Stabilisation of sodium caseinate hydrolysate foams. Food Research International, 41: 43-52.

Wang MY, Diane N, Gary A, Jarakae J, West B. 2008. Liver protective effects of Morinda citrifolia (noni). Plant Foods Hum Nutr. hal.5963

Wang MY, West BJ, Jensen CJ, Nowicki D, Anderson G, Chen X, et al. Morinada citrifolia (noni): a literature review and recent advances in Noni research. Acta Pharmacologica Sinica. 2002;23(12):1127- 41 